\title{
Updating the checklist of the alien flora in Egypt
}

\author{
Mohamed H. El-Beheiry', Hasnaa A. Hosni², Ahmed S. El-Din ${ }^{1}$, Salma K. \\ Shaltout $^{1 *}$, Dalia A. Ahmed ${ }^{1}$
}

${ }^{1}$ Botany Department, Faculty of Science, Tanta University, 31527, Tanta, Egypt.

${ }^{2}$ Botany and Microbiology Department, Faculty of Science, Cairo University, Cairo, Egypt.

*Corresponding author: salma.shaltout@science.tanta.edu.eg

\section{Abstract:}

The present study aims to update the list of the alien species in the Egyptian flora, which prepared from literature reviewing, field trips and herbaria consultation. The recent list includes 250 taxa (11.7\% of the Egyptian flora); including 5 subspecies and two varieties; related to 161 genera and 41 families. Three states of alien species are recognized: casuals (114 taxa), naturalized (129 taxa) and, invasive ( 7 taxa). The most represented life form is the therophytes. On the other hand, four geophytes-helophytes and three hydrophytes. Four major habitats supporting the distribution of these species: cultivated land, wetland, ruderal and natural habitats. The cultivated lands are the most represented. These alien taxa belong to 16 origins: 12 in the Old World (with 156 taxa) and four origin belong to New World (with 117 taxa), Pantropic (with four taxa) and palaeotropics (with 11 taxa). The same taxon may have more than origin. The most represented taxa were from South and Tropical America (58 taxa $=23.2 \%)$, South Asia $(51$ taxa $=$ $20.4 \%)$ followed by Europe $(38=15.2 \%)$. The highest taxa were recorded in family Poaceae (74), Amaranthaceae s.l. (25), Fabaceae (23), Asteraceae (20), Solanaceae (16) followed Euphorbiaceae (10 taxa).

Key words: casual species, Egypt, Invasive species, Naturalized species, New World, Old World, Urban habitats.

\section{Introduction:}

An alien plant is referred to as exotic, introduced, foreign, non-indigenous or nonnative plant. It has been introduced by humans intentionally or otherwise through human agency or accidentally from one region to another. An alien plant that has escaped from its original ecosystem and is reproducing on its own in the regional flora is considered a naturalized species (Lal, 2012). Many nonindigenous plant species have become components of the flora of any country. In Egypt, the studies of Shaltout (2014) could be considered as an introductory step towards studying this alien flora in Egypt.

The expanding field of invasion ecology has seen a proliferation of terms to describe various concepts. Alien species are not indigenous in a given geographical unit (i.e. country), regardless of their origin. In this

Received on 23/12/2019 and accepted on 21/03/2020 context, an alien species can be native of another country, or native of another continent. In the present study three alien categories were identified as follow: 1- Casual; alien plants that may flourish and even reproduce occasionally in an area, but which do not form self-replacing populations, and which rely on repeated introductions for their persistence (includes taxa labeled in the literature as adventives, waifs, transients, occasional escapes and persisting after cultivation). 2- Naturalized species; alien plants that reproduce consistently (casual) and sustain populations over many life cycles without direct intervention by humans; they often reproduce offspring freely, usually close to adult plants, and do not necessarily invade natural, semi-natural or humanmade ecosystems. 3- Invasive species; naturalized plants that produce reproductive offspring often in very large numbers, at considerable 
distances from parent plants (approximate scales: > $100 \mathrm{~m}$; over < 50 years for taxa spreading by seeds and other propagules; $>6$ $\mathrm{m}$ over 3 years for taxa spreading by roots, rhizomes, stolons, or creeping stem), and thus have the potential to spread over a considerable area. (Richardson et al., 2000).

The present study aims to achieve these points: updating and improvements the checklist of the alien taxa in the Egyptian flora previously prepared by Shaltout (2014), and providing an analysis of its origin and geographical patterns of the recorded taxa.

\section{Study Area}

Egypt lies between Africa and Asia, with long coast along Mediterranean Sea in the north (some $970 \mathrm{~km}$ ) and the Red Sea in the east (some $1100 \mathrm{~km}$ ). It occupies the northeastern corner of the African continent between Longitude: $30^{\circ} \quad 47^{\prime} \mathrm{E}$ and Latitude: $26^{\circ} 50^{\prime} \mathrm{N}$. It is roughly quadrangular, extending about $1073 \mathrm{~km}$ from north to south, and about $1229 \mathrm{~km}$ from east to west. Thus, its total area approximates one million $\mathrm{km}^{2}$. About quarter of its area lies to the south of the Cancer Tropic. This latitudinal location means that most of Egypt falls within Africa's dry desert region, except the narrow northern strip, which experiences a Mediterranean climate (Zahran and Willis, 2009).Its climate is affected by hot dry air masses over the Sahara, and the cooler, damper maritime air masses from the north (carried by east-ward moving depressions). Throughout most of the year, the hot dry tropical continental air masses dominate, but during the winter period air masses of both tropical and polar maritime origin make brief incursions into Egypt from the north, frequently bringing rain with them. It is characterized by a hot and almost rainless climate (Mashaly 1987, Zahran and Willis 2009).

\section{Materials and Methods:}

\section{1-Number and Categories of Alien Taxa:}

\section{a- Literature review:}

A previous list of 137 alien species in the Egyptian flora was prepared by Shaltout (2014). After consulting the following literature: Täckholm (1956 and 1974), Boulos \& El Hadidi (1974), El-Hadidi and Fayed
(1995), El-Hadidi and Hosni (2000) and Boulos (1999, 2000, 2002, 2005 and 2009) a new list was prepared. These references classified the alien species into three categories: casual, naturalized and Invasive according to Shaltout et al. (2016).

\section{b- Field trips:}

The taxa under study have been collected during 40 field trips in Egypt during the period from spring 2011 to winter 2018, covering some natural and anthropogenic habitat from phytogeographical regions: Nile Delta, Nile Valley, Faiyum depression, Oases, Mediterranean coastal region, Eastern and Western Deserts, (Fig. 1). The identification of the specimens was confirmed using the keys in the available references (Täckholm, 1974, Boulos, 19992005), and comparing them with specimens housed at the Herbaria of Tanta (TANE), Cairo University (CAI) and Agricultural Research Center (CAIM). All herbarium sheets were electronically scanned.

\section{c- Herbaria consultation:}

The species that the author could not collect from the field or from the previous literature were checked as herbarium specimens in the following herbaria: TANE, CAI and CAIM.

\section{2-Life Form:}

The life forms of the alien taxa were identified following the well-known system of Raunkiaer (1934). The life forms were as follows: phanerophytes, chamaephytes, hemicryptophytes, cryptophytes (geophytes, helophytes, or hydrophytes), therophytes and parasites.

\section{3- Habitat:}

The habitats of the alien species were detected by the author in the field during the field trips and the missing data were collected from relevant taxonomic literature such as Zohary (1966 and 1972), Feinbrun-Dothan (1978 and 1986), El-Hadidi \& Fayed (1995), Boulos (1999 - 2009), Ahmed (2009) and Shaltout et al. (2010).

\section{4-Native Range:}

The origin of alien species were detected by checking previously published floras including: Forsskål (1775), Delile (1813), Boissier (1867-1882), Ascherson and 


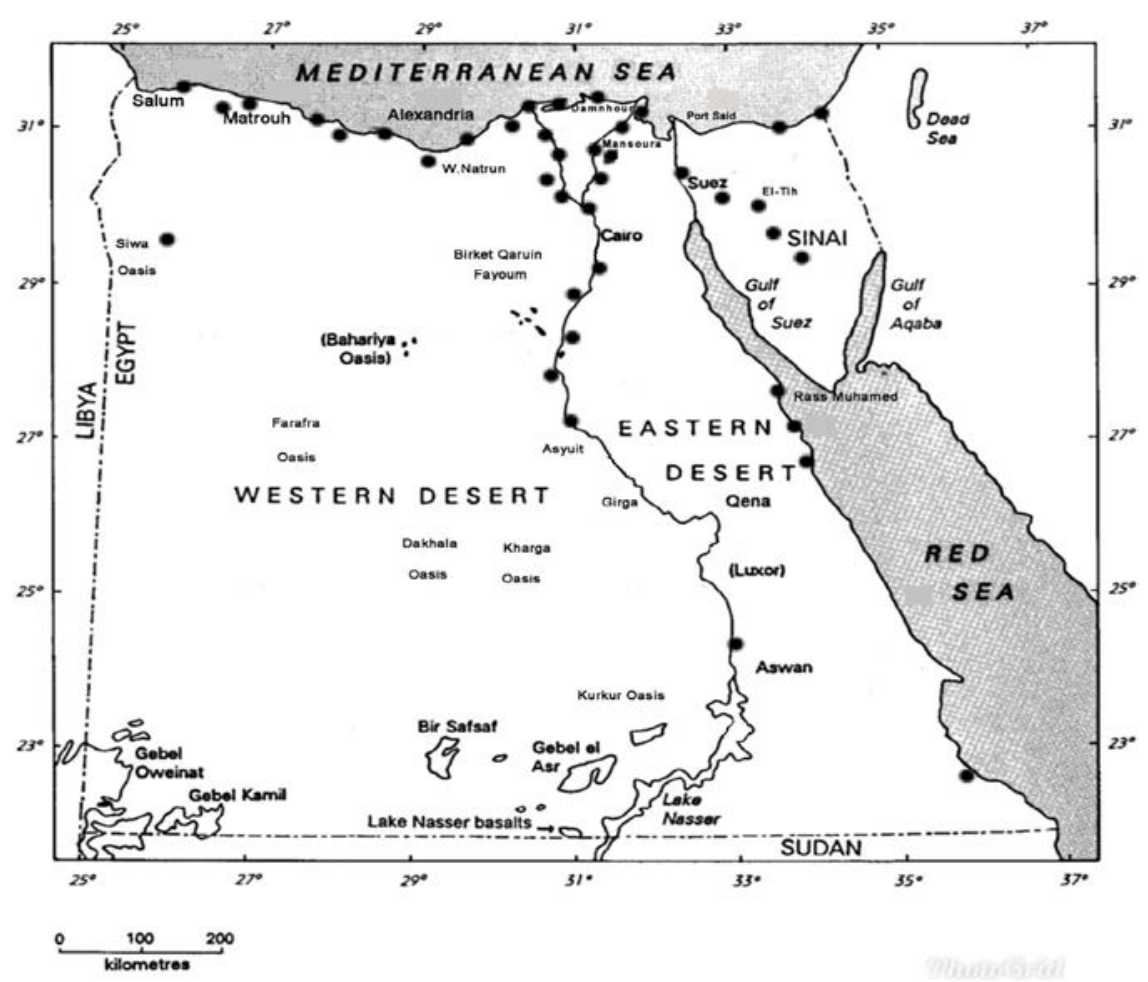

Fig. 1 Map of Egypt showing the visited areas (•).

Schweinfurth (1887 and 1889), Sickenberger (1901), Muschler (1912), Täckholm et al. (1941); Täckholm \& Drar (1950-1969), Täckholm (1956 and 1974), Bleser-Bircher (1998), El Hadidi \& Boulos (1988); Hepper (1998), Xuxley E. (1999); Boulos (19992009); and Ibrahim et al. (2016). Other regional Floras includes: Davis (1965-1985); Davis et al. (1988), Zohary (1966 - 1972); Feinbrun-Dothan (1978-1986); and Meikle (1977-1985)

The accepted names by stuff of CAI and TANE following the International Plant Names Index (https://www.ipni.org/, https://www.tropicos.org) and World Checklist of selected Plant Families (https://wcsp.science.kew.org); affiliation of taxa to families followed the approach of the Angiosperm Phylogeny Group (Stevens 2001 onwards, APG IV 2016). All herbarium specimens were scanned and kept in Herbarium of Tanta University (TANE).

\section{Results:}

\section{1- Number and categories of the Alien Species}

The alien flora of Egypt comprises 250 taxa (Appendix); three categories are recognized: causals, naturalized, and invasive. The naturalized taxa (129 taxa $=52.0 \%)$ are the most represented, followed by the causals (114 taxa $=45.6 \%)$, while the invasive species (7 taxa $=2.8 \%)$ less represented. One hundred and thirty- two of the total alien taxa were intentionally introduced, while 118 species were accidentally introduced. The intentional taxa are most concentrated in the casual category (89 taxa $=35.6 \%$ ), while the accidental species are most represented in naturalized category (96 taxa $=38.4 \%$ ), but all the invasive taxa are intentionally introduced, fig. (2).

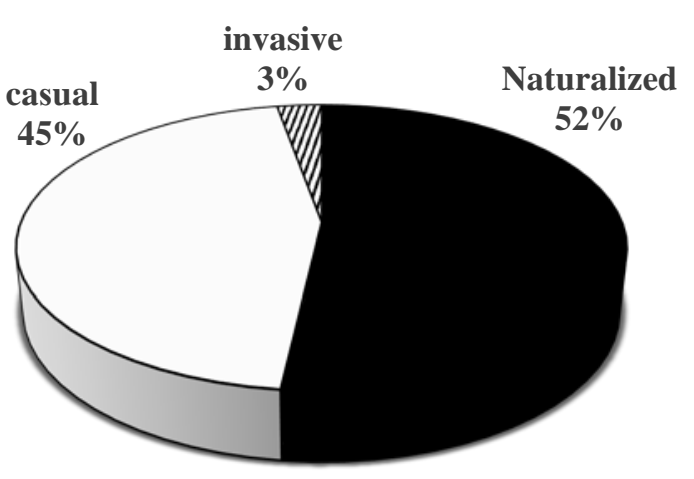

Fig. (2). Percentage number of alien species in the different recognized categories 


\section{2-Taxic Diversity:}

Pteridophyta are represented by only one family (Azollaceae) and one species; while Eudicots are represented by 37 families, 161 genera and 230 species; the richest families are
Poaceae: 74 taxa, Amaranthaceae (incl. Chenopodiaceae: 25 taxa) Fabaceae: 23 species, Asteraceae: 20 taxa, Solanaceae (16 taxa), and Euphorbiaceae (10 taxa), fig. (3).

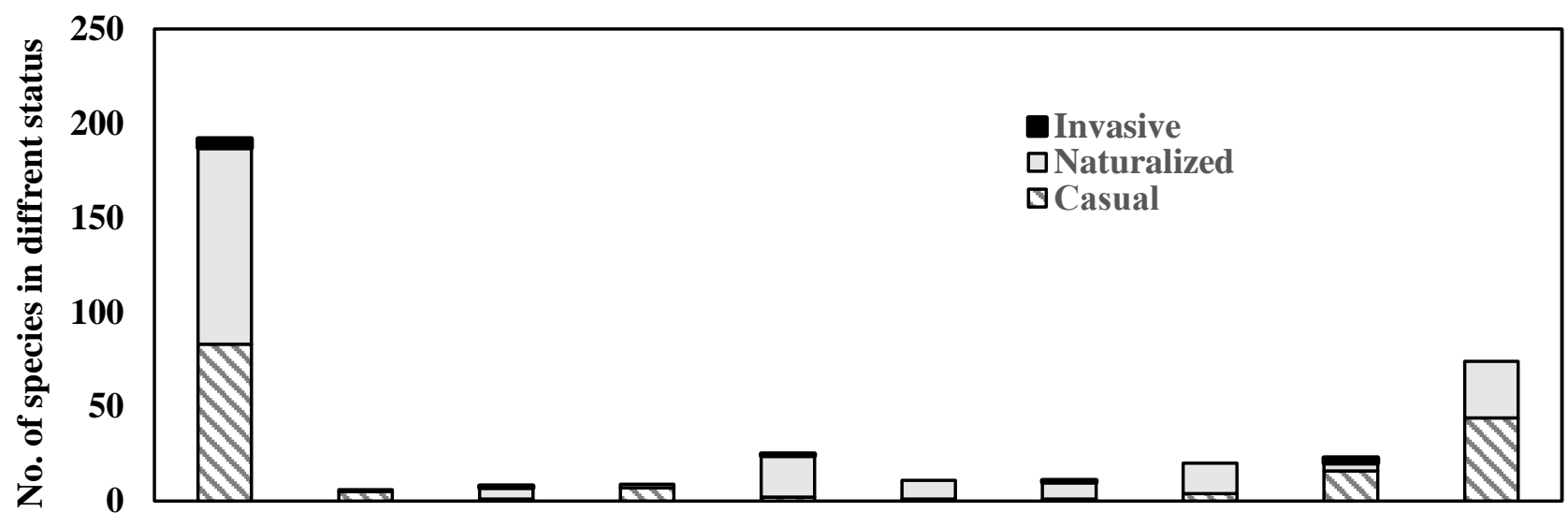

Total Solanacea Malvaceae Convolv. Amaranth. Brass. Euphorb. Asteraceae Fabaceae Poaceae Families

Fig. (3). Number of alien species in different families with more than 5 species in the three categories of the alien species in the Egyptian flora

\section{Life Form:}

Therophytes are the most represented life form (136 species $=54.4 \%$ of the total species), followed by phanerophytes (41 taxa $=16.4 \%$ ) and geophytes (32 taxa $=12.8 \%$ ). Hemicryptophytes are represented by 20 taxa (8\%), chamaephytes by 12 taxa (4.8\%). Most of the phanerophytes (20 taxa out of 41 ) and geophytes (24 taxa out of 32) are in the casual category (Fig. 4), while therophyte (80 taxa out of 136) and hemicryptophytes (12 taxa out of $20)$ are in casual category. Chamaephytes (7 taxa out of 12) and Geophyte-Helophyte (3 taxa out of 4) are mostly naturalized species. On the other hand, two of the three hydrophytes are invasive species.

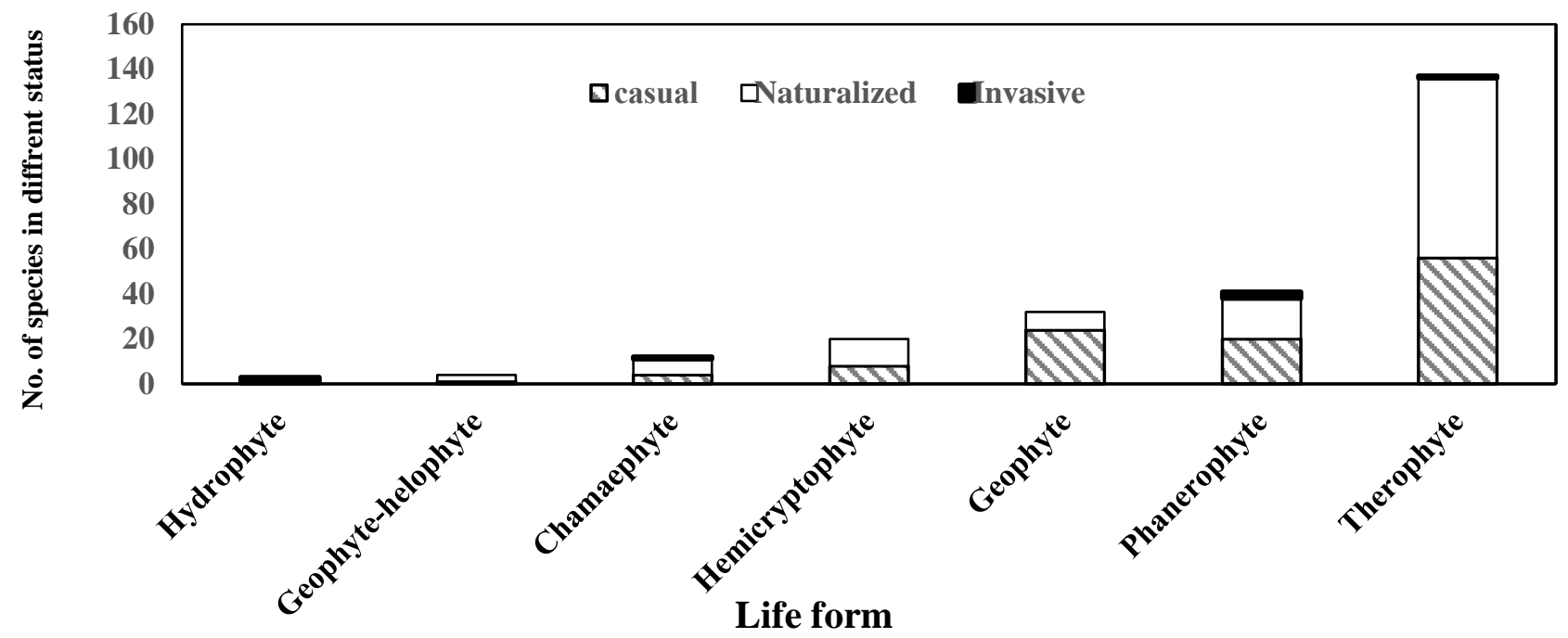

Fig. (4). Number of alien taxa in relation to their life form and alien category in the Egyptian flora 


\section{4- Habitat:}

Twenty-three habitats supporting the distribution of alien species in Egypt. They are categorized into four groups of habitats as follow, cultivated land are the most

represented (155 species $=52.5 \%)$, wetland, ruderal and natural habitat are the less represented (22 taxa $=7.4 \%)$, table $(1)$.

Table 1. Number of the alien plant taxa in their habitats in the Egyptian flora. Ac: absolute number and Rc: relative number (\%). Habitats are according to Shaltout et al (2016).

\begin{tabular}{|lccc|ll|}
\hline \multirow{2}{*}{ Habitat } & \multirow{2}{*}{ Casual } & \multirow{2}{*}{ Naturalized } & \multirow{2}{*}{ Invasive } & \multicolumn{2}{|c|}{ Alien } \\
\cline { 5 - 6 } & & & & Ac & Rc \% \\
\hline Cultivated land & 79 & 73 & 3 & 155 & 62 \\
Wetland & 23 & 40 & 3 & 66 & 26.4 \\
Ruderal & 12 & 36 & 4 & 52 & 20.8 \\
Natural & 6 & 15 & 1 & 22 & 8.8 \\
\hline
\end{tabular}

\section{5-Native Range:}

The alien taxa in the Egyptian flora belong to 24 origins divided into 12 origins in the Old World and 4 origins in the New World. One hundred and fifty- six taxa from the Old World distributed as follows: 87 from Asia, 38 from Africa, 38 from Europe and 10 from Mediterranean and 3 from Middle East; while 117 taxa from the New World distributed as follows: 104 of American origin and 13 of Australian origin, 4 Pantropic and 11 taxa palaeotropic (Table 2). The same taxon may have more than origin; four species with uncertain origin (Apium graveolens, Triticum aestivum and Laphangium luteoalbum) and two are cosmopolitan (Xanthium strumarium and Rorippa palustris).

Table 2. Number of alien taxa with their origin. N: north, S: South, W: West, E: East, T: Tropical and C: Central. Ac: absolute number and Rc: relative number (\%).

\begin{tabular}{|c|l|c|c|}
\hline \multicolumn{1}{|c|}{} & Origin & Ac & Rc \% \\
\cline { 2 - 4 } & N. Africa & 3 & 1.2 \\
\cline { 2 - 4 } & T. Africa & 18 & 7.2 \\
\cline { 2 - 4 } & S. Africa & 11 & 4.4 \\
\cline { 2 - 4 } & W. Africa & 2 & 0.8 \\
\cline { 2 - 4 } & E. Africa & 4 & 1.6 \\
\cline { 2 - 4 } & N. Asia & 4 & 1.6 \\
\cline { 2 - 4 } & S. Asia & 51 & 20.4 \\
\cline { 2 - 4 } & W. Asia & 10 & 4 \\
\cline { 2 - 4 } & E. Asia & 2 & 0.8 \\
\cline { 2 - 4 } & Middle East & 3 & 1.2 \\
\cline { 2 - 4 } & Europe & 38 & 15.2 \\
\cline { 2 - 4 } & Mediterranean & 10 & 4 \\
\cline { 2 - 4 } & Pantropic & 4 & 1.6 \\
\cline { 2 - 4 } & Palaeotropic & 11 & 4.4 \\
\hline \multirow{3}{*}{$\underset{3}{3}$} & N. America & 23 & 9.2 \\
\cline { 2 - 4 } & S. \& T. America & 58 & 23.2 \\
\cline { 2 - 4 } & C. America & 23 & 9.2 \\
\cline { 2 - 4 } & Australia & 13 & 5.2 \\
\hline Uncertain & & 4 & 1.6 \\
\hline Cosmopolitan & 2 & 0.8 \\
\hline
\end{tabular}




\section{Discussion:}

National inventories of alien plants are one of the key components for evaluating the status of biodiversity in a given country, as well as threats to endangered taxa, and provide source data for creating relevant indicators (Lambdon et al. 2008, Celesti- Grapow et al. 2010, Pyšek et al. 2012, van Kleunen et al. 2015, Latombe et al. 2016. Such data are needed for early warning systems, prioritization of management and implementation of effective policy measures (Brunel et al. 2010). The publication of checklists also helps neighboring countries to assess the threat from potential invasions of new taxa to arrive and checklists can contribute to the so-called horizon scanning exercises looking for potential new threats (Roy et al. 2014, Latombe et al. 2017).

This is the second comprehensive compilation and analysis of the available records on the alien plant taxa in Egypt. It provides the first assessment of their status, introduction purposes and main types of invaded habitats. It also pinpoints knowledge gaps in the geographic distribution and the quantification of environmental and economic impacts. The recorded alien taxa in the present study are 250 related to 161 genera and 41 families; they represent $11.7 \%$ of the total Egyptian flora; which are relatively low compared with the other countries. In Italy, 8043 taxa were recorded (Bartolucci et al. 2018), while France had 732 taxa, Spain had 495 taxa, Portugal had 261 taxa (Lambdon et al. 2008) and 340 in Turkey (Uludağ et al. 2017). In Egypt, forty one taxa were not recorded in the checklist of Boulos (2009) these including 29 casual, 9 naturalized and 3 invasive taxa. The first study by Shaltout et. al (2016) recorded 137 alien taxa related to 92 genera and 30 families. They represent 6.2\% of the total Egyptian flora. The present study indicates the dynamic pattern of the alien species in the Egyptian flora. One of the interpretations for the relatively low ratio for Egypt is the relatively short period used in the present study, which covers some 250-300 years only (since 1775 until now). This period is not long enough to include the history and evolution of the Egyptian flora.
In a country of ancient civilization like Egypt, it is impossible to decide definitely if the majority of weeds have originated from the native flora or have been introduced by man`s activity; there is no doubt that some weed species are really native to Egypt (Hassib 1951). Shaltout (2014) classified the alien species into five categories as follows: casuals, naturalized, environmental weeds, invasive and transformers. In the present study three main categories were adopted as follows: casual, naturalized and invasive species as proposed by Shaltout et al (2016). The result of the present study indicates that the cultivated lands have alien taxa higher than the other habitats (155 taxa), this may be attributed to high human activity. Detailed knowledge of the pool of alien naturalized taxa from which emerging invaders recruit can provide national authorities in Egypt with an instrument for prioritization of management measures and allocation of resources to those species where future spread, environmental and socioeconomic impacts are likely to occur (Brunel et al. 2010, Pergl et al. 2016, Rumferováfet al. 2016) form spectrum is thought to be either hereditary adjustment to the environment (El-Demerdash 1984), or representing the residual effects of some historical, climatic or biotic conditions on the plant population (Waisel 1972) As in case of the whole Egyptian flora, most of the alien species in the present study are therophytes followed by the phanerophytes. This trend is comparable to the whole flora of Egypt. The dominance of therophytes over the other life forms seems to be a response to the hot-dry climate, topographic variation and biotic influence (Heneidy and Bidak 1999).

The native range of the alien species in the present study belongs to 20 origins divided into 14 old world origins and the 6 new world origins. Severe invasions were due to the old world origins (171 species) as follows: Asia > Africa $>$ Europe $>$ Mediterranean region while the new world origins made fewer invasions (117 species) as follows: South America > North America > Australia. This may be 
interpreted in the view that the old world has been in close contact with Egypt since ancient history. In addition, the plant biodiversity in the old world are richer than that of the new world, which facilitates plant exchange. Although the new world is recently contacted with the old world (some 500 years, after the discovery of America); the number of species that invaded Egypt from it is not small in comparison with the number of alien species that came from other continents of the world.

The results of the present study may increase the awareness of alien taxa in Egypt and neighboring countries and trigger further dedicated specialized studies (e.g. Blackburn et al. 2014, Nentwig et al. 2016).

\section{Conclusion:}

In conclusion, the present study may provide information on the number and status of alien taxa to fill a gap with respect to these taxa in Egypt. It revealed that the total number of the alien taxa in the Egyptian flora was 250 species, belonging to 106 genera and 31 families; this contributes $11.7 \%$ of the total flora of Egypt; most of these taxa are of South American origin (23.6\% of the total alien flora) and of South Asian origin ( $20.8 \%$ ). Therophytes were the most represented life form, followed by phanerophytes; geophyteshelophytes was the less represented. Four major groups of habitats supporting the distribution of alien species in Egypt: cultivated, wet land, ruderal and natural habitats Further studies are needed to report the spreading of newly introduced, and naturalized taxa which may arrive and spread in Egypt, causing serious problems and affected the ecosystem. Thus, we hope that publishing this list will encourage further recording so that the impacts of these species can be minimized and controlled.

\section{Acknowledgements:}

The authors would like to beholden to Dr. Kamal Hussien Shaltout, Prof. of Plant Ecology, Botany Department, Faculty of Science, Tanta University for his supportive efforts. Also, we wish to thank an anonymous referee for the great efforts, which he made to correct some details in this paper.

\section{References:}

Angiosperm Phylogeny Group (2016). An update of the Angiosperm Phylogeny Group Classification for the orders and families of flowering plants: APG IV. Bot. Jour. Linn. Soc. 181: 1-20.

Ascherson, P. \& Schweinfurth, G. (1887). Illustration de la Flore d`Égypte. Mém. Inst. Égypt: 2(1):25-260

Ascherson, P. \& Schweinfurth, G. (1889). Supplement an l' Illustration de la Flore d' Égypte. Mém. Inst. Égypt: $821-745$

Bartolucci, F., Peruzzi, L., Galasso, G., Albano, A., Alessandrini, A, Ardenghi, N, M. G., Astuti, G., Bacchetta, G., Ballelli, S., Banfi, E., Barberis, G., Bernardo, L. et al. (2018). An updated checklist of the vascular flora native to Italy, Pl.Biosyst. 152(2): 179303. DOI: 10.1080/11263504.2017.1419996

Blackburn, T.M., Essl, F., Evans T., Hulme, P.E., Jeschke JM.., Kühn I., Kumschick S., Marková Z., Mrugała A., Nentwig W., Pergl J., Pyšek P., Rabitsch W., Ricciardi A., Richardson D.M., Sendek A, Vilà M, Wilson J.R.U., Winter M., Genovesi P. \& Bacher S. (2014). A unified classification of alien species based on the magnitude of their environmental impacts. PLoS Biology 12: e1001850.

Bleser-Bircher, W. (1998). Delchevalerie "Les plantes exotiques cultiveés en Egypte", an updated English version. Taeckholmia 18 (2): 1-111.

Boissier, E. (1867-1882). Flora Orientalis. vols: 1-5. Basel-Genevae. 1017,1159,1033, 1276, 868 pp.

Boulos, L. (1999). Flora of Egypt. vol. 1: Azollaceae- Oxalidaceae Al-Hadara Publishing, Cairo, Egypt. 419 pp.

Boulos, L. (2000). Flora of Egypt. vol. 2: Verbenaceae - Boraginaceae. Al-Hadara Publishing, Cairo, Egypt. 352 pp.

Boulos, L. (2005). Flora of Egypt. vol. 3: Verbenaceae- Compositae Al-Hadara Publishing, Cairo, Egypt. 373 pp.

Boulos, L. (2005). Flora of Egypt. vol. 4: Alismataceae- Orchidaceae. Al-Hadara Publishing, Cairo, Egypt. 617 pp.

Boulos, L. (2009). Flora of Egypt Checklist Revised Annotated Edition. Al-Hadara Publishing, Cairo. Egypt. 410 pp. 
Boulos, L. \& El Hadidi, M.N. (1994). Weed Flora of Egypt (revised ed.)- American University in Cairo Press. Cairo 361pp.

Brunel, S., Schrader, G., Brundu, G., Fried, G. (2010). Emerging invasive alien plants for the Mediterranean Basin. EPPO Bull. 40: 219$238 . \quad$ https://doi.org/10.1111/j.13652338.2010.02378.x

Davis, P. H. (ed.), (1965-1985). Flora of Turkey and the east Aegean Islands. vol. 1-9. Edinburgh University Press, Edinburgh. 567, 581, 628,657, 890, 823, 947,632,724 Pp

Davis P. H., Mill R.R. \& Tan K. (eds.) (1988). Flora of Turkey and the East Aegean Islands, vol. 10. Edinburgh University Press, Edinburgh. 589 pp

Delile, R. (1813). Description de l'Égypte, Histoire Naturelle, Explication Des Planches 2. Paris. pp.145-320

El-Demerdash, M. A. (1984). Ecological studies on Juncus plants. Ph. D. Thesis, Mansoura University, Mansoura. (Unpublished)

El-Hadidi, M. \& Boulos, L. (1988). The Street Trees of Egypt, (revised ed.). The American University in Cairo Press, Cairo. $130 \mathrm{pp}$.

El-Hadidi, M. \& Fayed, A. (1994/95). Material for Excursion Flora of Egypt (EFE). Taeckholmia 15: 1-233.

El-Hadidi, M. \& Hosni, H. A. (2000). Conservation and threats in: M. N. El-Hadidi (ed.) Flora Aegyptiaca vol. 1(1), Palm Press and Cairo University Herbarium. Cairo. pp. 105-180.

Feinbrun, N. (1978-1986). Flora Palaestina. Parts 3, 4. Israel Academy of Science and Humanities, Jerusalem. 481, 462 pp.

Forsskål, P. (1775). Flora Aegyptiaco Arabica. Hanuniae, 219 pp.

Harper, J. L. (1977). Population Biology of Plants. New York, NY: Academic Press. 900 pp.

Hassib, M. (1951). Distribution of plant communities in Egypt. Bull. Fac. Sci. Fouad I Univ. 29: 59- 261.

Heneidy, S. Z. \& Bidak, L. M. (1999). Physical defenses and aversion factor of some forage plant species in the Western Mediterranean coastal region of Egypt. Jourl Union Arab Biol. 9 (B): 15-30.
Hepper, F.N. (1998). Solanaceae in M.N.El Hadidi (ed.) Flora of Egypt. Taeckholmia Add. Ser. 6:1-168.

Ibrahim, K.; Hosni, H. \& Peterson, P. (2016). Grasses of Egypt. Smithonian Contr. Bot. 103: 1-201.

Lambdon, P.W., Pyšek, P., Basnou, C. et.al. (2008). Alien flora of Europe: species diversity, temporal trends, geographical patterns and research needs. Preslia 80: 101149.

Meikle, R.D. (1977- 1985). Flora of Cyprus. vols 1,2. Royal Botanic Gardens, Kew, 1969 pp.

Muschler, R. (1912). A Manual Flora of Egypt. vol.1, 2. Berlin 1312 pp.

Nentwig, W., Bacher, S., Pyšek, P., Vilà, M. \& Kumschick, S. (2016). The generic impact scoring system (GISS): a standardized tool to quantify the impacts of alien species. Environ. Monit. Assess. (2016) 188: 315

DOI 10.1007/s10661-016-5321-4

Pergl, J., Sádlo, J., Petrusek, A., Laštůvka, Z., Musil, J., Perglová, I., Šanda, R., Šefrová, H., Šíma, J., Vohralík V. \& Pyšek, P. (2016). Black, Grey and Watch Lists of alien species in the Czech Republic based on environmental impacts and management strategy. NeoBiota 28: 1-37.

Pyšek P., Danihelka J., Sádlo J., Chrtek Jr J., Chytrý M., Jarošík V., Kaplan Z., Krahulec F., Moravcová L., Pergl J., Štajerová K. \& Tichý L. (2012). Catalogue of alien plants of the Czech Republic (2nd ed.): Checklist update, taxonomic diversity and invasion patterns. Preslia 84: 155-255.

Raunkiaer, C. (1934). The Life Forms of Plants and Statistical Plant Geography. Oxford University Press, London.

Richardson, D.M. Pyssek, P. Rejmanek, M. Barbour, M.G. Panetta, F.D. \& West, C.J. (2000). Naturalization and invasion of alien plants: concepts and definitions. Diversity and Distribution 6: 93-107.

Roy H.E., Peyton J., Aldridge D.C., Bantock T., Blackburn T.M., Britton, R., Clark, P., Cook, E., Dehnen- Schmutz,K., Dines, T., Dobson, M., Edwards, F., Harrower, C., Harvey, M.C., Minchen,D., Noble. D.G., Parrott, D., Pocock, M.J., Preston, C.D. Roy, S., Salisbury, A., Schonrogge, K., Sewell, J., Shaw, R.H., Stebbing, P., 
Stewart, A.J. \& Walker, K.J. (2014). Horizon scanning for invasive alien species with the potential to threaten biodiversity in Great Britain. Glob.Chang. Bio 20(12):3859-71. doi: 10.1111/gcb.12603. Epub 2014 May 19

Rumlerová ,Z., Vilà, M., Pergl, J., Nentwig, W. \& Pyšek P (2016). Scoring environmental and socio-economic impacts of alien plants invasive in Europe. Biological Invasions 18: 3697-3711.

Shaltout K. H. Hosni H. A., El-Kady H. F., El-Beheiry M. A. \& Shaltout S. K. (2016). Composition and pattern of alien species in the Egyptian flora, Flora 222: 104-110

Shaltout, S. K. (2014). Ecological study on the alien species in the Egyptian flora, M.Sc. thesis, Faculty of Science, Tanta University, Tanta, 191 Pp (Unpublished)

Shankar, H. L., Singha, S. Kumara, A., Mishrab, P.K. \& Mishra, K. (2012). Study of invasive and alien species in Jharkhand, India and its impact on Environment. The Journal of Ethnobiology and Traditional Medicine. Photon 117: 167-177.

Sickenberger, E. (1901). Contributions a la Flore d'Egypte. Mém. Inst. Égypt. 4 (2): 167335.

Stevens, P. F. (2001 onwards). Angiosperm Phylogeny Website. Version 14, July 2017 [and more or less continuously updated since]http://www.mobot.org/MOBOT/research/AP web/.Page last updated: 01/27/2020

Täckholm, V. (1956). Students' Flora of Egypt. Anglo-Egyptian Bookshop, Cairo, 649 pp.
Täckholm, V. (1974). Students' Flora of Egypt: $2^{\text {nd }}$ ed. Cairo University, 888 pp.

Täckholm, V. \& Boulos, L. (1974). Supplementary notes to the Students' Flora of Egypt. Publ. Cairo Univ. Herb. 5:1-133

Täckholm, V. \& Drar, M. (1950-1969). Flora of Egypt vols. 2-4. Bull. Fac. Sci. Cairo Univ. no 28,30,36: 1-547, 1-644, 1-423.

Täckholm, V., Täckholm, G. \& Drar, M. (1941). Flora of Egypt vol.1. Bull. Fac. Sci. Cairo Univ. no 17: 1-574

Uludağ, A., Aksoy, N., Yazlık, A., Arslan, Z., Yazmış,E., Üremiş, I., Cossu T, Groom, Q., Pergl, J., Pyšek P. \& Brundu, G. (2017). Alien flora of Turkey: checklist, taxonomic composition and ecological attributes. NeoBiota 35:62-85.

Van Kleunen, M., Dawson, W., Essl, F. et al. (2015). Global exchange and accumulation of non-native plants. Nature 525: 100-103. https://doi.org/10.1038/nature14910

Waisel, Y. (1972). Biology of halophytes. Academic Press, New York. 395 pp

Xuxley, A. (1999). In M. Grifiths (ed.). The new royal horticulture society Dictionary of Gardening. The New Royal Horticltural Society, Macmillan References LTD, London, UK.3000 pp

Zahran, M. A. \& Willis, A. J. (2009). The Vegetation of Egypt, 2nd ed. Springer. 437 pp. Zohary, M. (1966-1972). Flora Palaestina. Parts 1,2. Israel Academy of Science and Humanities, Jerusalem. 364, 482 pp. 
Appendix: Characteristics of the alien taxa in the Egyptian flora. (Vernacular name after Täckholm 1974). The species that was not recorded in the checklist of Boulos (2009) was marked by (*). The taxa are arranged in Alphabetical order. (E: East; C: Central; S: South; T: Tropical; W: West; SE: Southeast; SW: Southwest; TS: Tropical-South, TW: Tropical west, TE: Tropical east; Temp.: Temperate)

\begin{tabular}{|c|c|c|c|c|}
\hline Scientific name & Vernacular name & Family & Life form & Native range \\
\hline \multicolumn{5}{|l|}{ Casual } \\
\hline Acacia farnesiana* (L.) Willd. & فتنـه & Fabaceae & Phanerophyte & T. \& subtropical America \\
\hline Ageratum houstonianum Mill. & - & Asteraceae & Therophyte & C. America \\
\hline Alcea rosea $\mathrm{L}$. & خطمية & Malvaceae & Hemicryptophyte & E. Asia \\
\hline Allium cepa L. & بصل & Amaryllidaceae & Geophyte & W. Asia \\
\hline Allium sativum L. & ثوم & Amaryllidaceae & Geophyte & C. Asia \\
\hline Alternanthera pungens Kunth & - & Amaranthaceae & Hemicryptohyte & S. America \\
\hline Althaea ludwigiu L. & خطمة & Malvaceae & Therophyte & S. Africa \\
\hline Apium graveolens L. & كرفس & Apiaceae & Therophyte & Unknown \\
\hline Artemisia scoparia Waldst. \& Kit. & - & Asteraceae & Therophyte & Europe, Temp. Asia \\
\hline Arundo donax L. & غاب بلدى & Poaceae & Geophyte-Helophyte & Mediterranean \\
\hline Avena sativa $\mathrm{L}$. & زمير & Poaceae & Therophyte & Middle East \\
\hline Bauhinia variegata* L. & خف الجمل & Fabaceae & Phanerophyte & S. Asia (India \& China) \\
\hline Beta vulgaris subsp. maritima (L.) Arcang. & بنجر & Amaranthaceae & Therophyte & Europe, N. Africa, and S. Asia \\
\hline Brassica oleracea* var. oleracea & 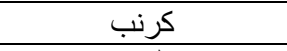 & Brassicaceae & Therophyte & W. Europe \\
\hline Brassica rapa L.var.rapa & لفت & Brassicaceae & Therophyte & N. Europe, E. Asia \\
\hline Briza maxima L. & - & Poaceae & Therophyte & S. Africa \\
\hline Briza minor L. & - & Poaceae & Therophyte & Mediterranean \\
\hline Bromus lepidus Holmb. & & Poaceae & Geophyte & Europe \\
\hline Casuarina equisetifolia* L. & جزوارين & Casuarinaceae & Phanerophyte & SE Asia to NE Australia and Pacific Islands \\
\hline Casuarina stricta* L. & جزوارين & Casuarinaceae & Phanerophyte & SE Australia \\
\hline Cenchrus americanus (L.) Morrone & ذيل الفار & Poaceae & Therophyte & Palaeotropical \\
\hline Cenchrus ciliaris L. & رجل الغر اب & Poaceae & Hemicryptophyte & Palaeotropical \\
\hline Cenchrus clandestinum (Hochst. ex Chiov.) Morrone & - & Poaceae & Geophyte & $\mathrm{T}$, Africa \\
\hline Cenchrus longisetus M.C.Johnst. & - & Poaceae & Geophyte & E. Africa and Arabia. \\
\hline Centaurea calcitrapa L. & شوك & Asteraceae & Chamaephyte & Middle East, C. Europe \\
\hline Chloris virgata Sw. & - & Poaceae & Therophyte & Palaeotropical \\
\hline Chrysopogon zizanioides (L.) Roberty & نجيل الهند & Poaceae & Geophyte & S. Asia (India) \\
\hline Citrullus lanatus* (Thunb.) Mastum \& Naki & بطيخ & Cucurbitaceae & Therophyte & Pantropical \\
\hline Clitoria ternatea $\mathrm{L}$. & عرق العقرب & Fabaceae & Phanerophyte & S. Asia \\
\hline Coix lacryma-jobi L. & 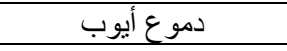 & Poaceae & Therophyte & S. Asia \\
\hline Coriandrum sativum L. & كزبرة & Apiaceae & Therophyte & S. Europe \\
\hline Cortaderia selloana (Schult. \&Schult.f.) Asch. \& Graebn. & حلفا & Poaceae & Geophyte & S. America (Brazil, Argentina, Paraguay) \\
\hline Cotula anthemoides L. & - & Asteraceae & Therophyte & Palaeotropical \\
\hline
\end{tabular}


Mohamed H. El-Beheiry et al.

\begin{tabular}{|c|c|c|c|c|}
\hline Scientific name & Vernacular name & Family & Life form & Native range \\
\hline Cucumis melo* L. & خيار & Cucurbitaceae & Therophyte & Probably from W. Africa \\
\hline Cucurbita pepo* L. & قرع عسلي & Cucurbitaceae & Therophyte & Probably from N. America \\
\hline Cyclosprmum leptophyllum (Pers.) Sprague & & Apiaceae & Therophyte & C. America \\
\hline Cymbopogon citratus (DC.) Stapf & حشيشة الليمون & Poaceae & Geophyte & S. Asia (S. India \& Sri Lanka) \\
\hline Cymbopogon flexuosus (Nees ex Steud.) Watson & حشيشة الليمون & Poaceae & Geophyte & S. Asia (India) \\
\hline Cymbopogon jwarancusa (Jones) Schult. & - & Poaceae & Geophyte & S. Asia (India) \\
\hline Cymbopogon martini (Roxb.) J. F. Watson in Atkins. & - & Poaceae & Geophyte & S. Asia (India) \\
\hline Cymbopogon nardus (L.) Rendle & - & Poaceae & Geophyte & S. Asia \\
\hline Cyperus involucratus Rottb. & - & Cyperaceae & Geophyte & T. Africa \\
\hline Dactylis glomerata L. & - & Poaceae & Geophyte & N. Asia \& Europe \\
\hline Desmodium tortuosum* (Sw.) DC. & - & Fabaceae & Therophyte & T. America \\
\hline Ehrharta calycina Sm. & - & Poaceae & Geophyte & S. Africa \\
\hline Eleusine coracana (L.) Gaertn. & بشنه & Poaceae & Therophyte & S. America and S. Asia (India) \\
\hline Eleusine floccifolia (Forssk.) Spreng. & - & Poaceae & Geophyte & NE T. Africa and SW Arabia \\
\hline Eleusine indica (L.) Gaertn. & نجيل & Poaceae & Therophyte & S. Asia (India) \\
\hline Elodea canadensis Michx. & 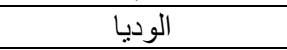 & Hydrocharitaceae & Hydrophyte & N. America \\
\hline Eragrostis tef (Zucc.) Trott. & - & Poaceae & Therophyte & E. Africa (Ethiopia) \\
\hline Eruca vesicaria* (L.) Cav. & جرجير & Brassicaceae & Therophyte & Middle East-West Asia \\
\hline Eucalyptus camaldulensis* Dehn. & كافور & Myrtaceae & Phanerophyte & Australia \\
\hline Euphorbia nutans Lag. & - & Euphorbiaceae & Therophyte & N. America \\
\hline Ficus retusa L. * & فيكس & Moraceae & Phanerophyte & S. Asia (Philippines to N Borneo) \\
\hline Foeniculum vulgare Mill. subsp. vulgare & شُبت & Apiaceae & Hemicryptophyte & Europe \\
\hline Gisekia pharnaceoides L. & - & Gisekiaceae & Therophyte & Palaeotropical \\
\hline Hedysarum coronarium L. & - & Fabaceae & Therophyte & Europe (Italy) \\
\hline Heliotrobium curassavicum Vahl & - & Boraginaceae & Chamaephyte & T. America \\
\hline Hibiscus esculentus* L. & بامية & Malvaceae & Phanerophyte & S. Asia \\
\hline Hibiscus sabdariffa L. & كر كديه & Malvaceae & Therophyte & S. Asia and (Africa)? \\
\hline Hordeum vulgare L. & شعبر & Poaceae & Therophyte & S. Asia (India) \\
\hline Ipomoea cairica (L.) Sweet & ست الحسن & Convolvulaceae & Geophyte & T. Africa and S. Asia \\
\hline Khaya senegalensis* (Desv.) A. Juss & كايا & Meliaceae & Phanerophyte & TW Africa \\
\hline Lablab purpureus* (L.) Sweet. & 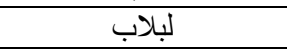 & Fabaceae & Chamaephyte & T. Africa \\
\hline Lepidium draba L. & - & Brassicaceae & Hemicryptophyte & S. Europe \\
\hline Lepidium sativum L. & حب الرشاد & Brassicaceae & Therophytes & Eastern Mediterranean to S Asia (India) \\
\hline Linum usitatissimum L. & كتان & Linaceae & Therophyte & Europe \\
\hline Luffa cylindrica* (L.) M. Roem. & لوف & Cucurbitaceae & Phanerophyte & S. Asia \& T/ Africa \\
\hline Lupinus albus Schreb. & ترمس & Fabaceae & Therophyte & S. Europe \\
\hline Lycopersicon esculentum* P. Mill. & طماطم & Solanaceae & Hemicryptophyte & T. America \\
\hline Mangifera indica* $\mathrm{L}$. & مانجو & Anacardiaceae & Phanerophyte & N. America \\
\hline Medicago sativa L. & نفل & Fabaceae & Therophyte & W. Asia \\
\hline
\end{tabular}


Updating the checklist of the alien flora in Egypt

\begin{tabular}{|c|c|c|c|c|}
\hline Scientific name & Vernacular name & Family & Life form & Native range \\
\hline Melinis minutiflora P. Beauv. & - & Poaceae & Geophyte & T. Africa \\
\hline Melinis repens (Willd.) Zizka subsp. grandiflora (Hochst.) Zizka & - & Poaceae & Therophyte & T. Africa \\
\hline Mentha pulegium L. & ن ن أناع & Lamiaceae & Chamaephyte & W. and C. Europe, Middle East, N. Africa \\
\hline Mimosa pigra L. & - & Fabaceae & Phanerophyte & S. America \\
\hline Miscanthussinensis Anderson & - & Poaceae & Geophyte & Europe \& SE Asia (China, Japan, Korea) \\
\hline Momordica balsamina L. & - & Cucurbitaceae & Therophyte & Palaeotropcal \\
\hline Morus alba* L. & توت ابيض & Moraceae & Phanerophyte & S. Asia (China) \\
\hline Morus nigra* L. & توت أسود & Moraceae & Phanerohyte & SW Asia \\
\hline Nigella sativa L. & حبة البركة & Ranunculaceae & Therophyte & W. \& S. Asia (India) \\
\hline Oryza sativa L. & 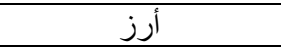 & Poaceae & Therophyte & SE Asia \\
\hline Parkinsonia aculeata* L. & شوكة القدس & Fabaceae & Phanerophyte & T. America \\
\hline Paspalum racemosum Lam. & & Poaceae & Therophyte & S. America \\
\hline Petroselinum crispum (Mill.) A. W. Hill. & بقدونس & Apiaceae & Therophyte & Europe, W. Asia \\
\hline Phalaris aquatica L. & - & Poaceae & Geophyte & Mediterranean \\
\hline Pisum sativum L. & بسلة & Fabaceae & Therophyte & Europe \\
\hline Psidium guajava* $\mathrm{L}$. & جو افة & Myrtaceae & Phanerophyte & T. America \\
\hline Raphanus sativus* L. & فجل & Brassicaceae & Therophyte & Europe \\
\hline Rorippa palustris (L.) Besser & - & Brassicaceae & Therophyte & Subcosmopolitan \\
\hline Saccharum officinarum L. & قصب السكر & Poaceae & Geophyte & S. \& SE Asia \\
\hline Schinus terebinthifolius* Raddi. & فلفل عريض & Anacardiaceae & Phanerophyte & S. America (Brazil to Argentina) \\
\hline Sesbania sericea (Willd.) Link & - & Fabaceae & Therophyte & T. Africa \\
\hline Setaria italic (L.) P. Beauv. & - & Poaceae & Therophyte & Europe \\
\hline Sida acuta Burm.f. & - & Malvaceae & Geophyte & Pantropical \\
\hline Solanum diphyllum* L. & - & Solanaceae & Phanerophyte & C. America \\
\hline Solanum melongena* L. & باذنجان & Solanaceae & Phanerophyte & S. Asia and S. Africa \\
\hline Sorghum bicolor (L.) Moench & & Poaceae & Therophyte & S. Africa \\
\hline Sorghum halepense (L.) Pers. & حشيش الفرس، جراوة & Poaceae & Geophyte & Mediterranean \\
\hline Sorghum $x$ drummondi (Nees ex Steud.) Millsp. \& Chase & - & Poaceae & Therophyte & Cultivated in the old world tropic \\
\hline Sporobolus natalensis (Steud.) T. Durand \& Schinz & - & Poaceae & Hemicryptophyte & S. Africa \\
\hline Sporobolus wrightii Munro ex Scribn. & - & Poaceae & Geophyte & N. \& C. America \\
\hline Themeda villosa (Poir.) A. Camus in Lecomte & & Poaceae & Hemicryptophyte & SE Asia \\
\hline Trifolium incarnatum L. & - & Fabaceae & Therophyte & S. Europe \\
\hline Trigonella foenum-graecum* L. & حلبة & Fabaceae & Therophyte & SW Asia \\
\hline Triticum aestivum L. & قمح & Poaceae & Therophyte & Not known? \\
\hline Triticum dicoccum (Schrank) Schubl. & قمح & Poaceae & Therophyte & S. and E. Europe, Temp. Asia \\
\hline Urochloa mutica (Forssk.) T.Q.Nguyen & مضيد & Poaceae & Therophyte & Pantropical \\
\hline Vicia faba* L. & فول & Fabaceae & Therophyte & N. Africa, SW Asia \\
\hline Vigna unguiculata (L.) Walp subsp.Sesquipedalis (L.) Verdc. & 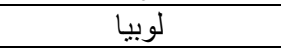 & Fabaceae & Therophyte & T. Africa (uncertain) \\
\hline Viola tricolor L. & بانسية & Violaceae & Therophyte & Europe \\
\hline
\end{tabular}


Mohamed H. El-Beheiry et al.

\begin{tabular}{|c|c|c|c|c|}
\hline Scientific name & Vernacular name & Family & Life form & Native range \\
\hline Vitis vinifera* $\mathrm{L}$. & عنب & Vitaceae & Phanerophyte & Mediterranean, SW Asia, C. Europe \\
\hline Zea mays L. & ذرة شامى & Poaceae & Therophyte & C. America \\
\hline Zea mexicana (Schard.) Reeves \&Mangelsd. & ذرة ريانه & Poaceae & Therophyte & C. America (Mexico) \\
\hline \multicolumn{5}{|l|}{ Naturalized } \\
\hline Abutilon theophrasti Medik. & حنبوك & Malvaceae & Therophyte & Palaeotropical \\
\hline Acrachne racemosa (B. Hyne ex Roem. \& Schult.) Ohwi & - & Poaceae & Therophyte & T. Africa \\
\hline Alopecurus myosuroides Huds. & ثُعلبية & Poaceae & Therophyte & S. Europe \\
\hline Alternanthera bettzickiana* (Regel) Voss & - & Amaranthaceae & Therophyte & C. and S. America (Maxico and Argentina) \\
\hline Alternanthera nodiflora* R.Br. & - & Amaranthaceae & Therophyte & T. Africa \& S. Asia \\
\hline Amaranthus albus L. & & Amaranthaceae & Therophyte & N. America \\
\hline Amaranthus blitoides S. Watson & - & Amaranthaceae & Therophyte & W. of N. America \\
\hline Amaranthus caudatus L. & عرف الديك & Amaranthaceae & Therophyte & S. America \\
\hline Amaranthus cruentus L. & رعاف & Amaranthaceae & Therophyte & T. America \\
\hline Amaranthus hybridus L. & رعاف & Amaranthaceae & Therophyte & N. America \\
\hline Amaranthus lividus L. & - & Amaranthaceae & Therophyte & Pantropical \\
\hline Amaranthus palmeri S. Watson & - & Amaranthaceae & Therophyte & N. and C. America (Mexico) \\
\hline Amaranthus retroflexus L. & - & Amaranthaceae & Therophyte & N. America \\
\hline Amaranthus spinosus L. & سندار - ضوح & Amaranthaceae & Therophytes & T. America \\
\hline Amaranthus tricolor L. & - & Amaranthaceae & Therophyte & S. Asia \\
\hline Ambrosia artemisiifolia L. & - & Asteraceae & Therophyte & N. America \\
\hline Argemone mexicana L. & - & Papaveraceae & Therophyte & S. America \\
\hline Atriplex canescens (Pursh) Nutt. & قطف & Amaranthaceae & Phanerophyte & N. America \\
\hline Atriplex holocarpa F. Muell. & قطف & Amaranthaceae & Therophyte & Australia \\
\hline Atriplex lindleyi subsp. Inflate (F. Muell.) P. G. Wilson & قطف & Amaranthaceae & Therophyte & Australia \\
\hline Atriplex nummularia Lindl. & قطف & Amaranthaceae & Phanerophyte & Australia \\
\hline Atriplex semibaccata R. Br. & قطف & Amaranthaceae & Therophyte & Australia \\
\hline Atriplex suberecta Verd. & قطف & Amaranthaceae & Therophyte & Australia, S. Africa \\
\hline Bidens bipinnata L. & - & Asteraceae & Therophyte & N. \& S. America, Europe and Asia \\
\hline Bidens pilosa L. & - & Asteraceae & Therophyte & T. America \\
\hline Blainvillea acmella (L.) Philipson & - & Asteraceae & Therophyte & T. S. America \\
\hline Bromus catharticus Vahl & خافور & Poaceae & Therophyte & S. America \\
\hline Bromus inermis Leyss. & - & Poaceae & Geophyte & Europe \\
\hline Canna indica* L. & كنا & Cannaceae & Phanerophyte & S. and C. America \\
\hline Cenchrus biflorus Roxb. & السافية & Poaceae & Therophyte & T. Africa, Arabia, S. Asia (India) \\
\hline Cenchrus echinatus L. & - & Poaceae & Therophyte & T. America \\
\hline Ceratonia siliqua L. & - & Fabaceae & Therophyte & Mediterranean \\
\hline Chenopodium botrys L. & فِس الكلب، مِنِنِنَة & Amaranthaceae & Chamaephyte & S. America \\
\hline Chenopodium giganteum D. Don & - & Amaranthaceae & Therophyte & S. Asia (India) \\
\hline
\end{tabular}


Updating the checklist of the alien flora in Egypt

\begin{tabular}{|c|c|c|c|c|}
\hline Scientific name & Vernacular name & Family & Life form & Native range \\
\hline Chloris pycnothrix Trin. & - & Poaceae & Therophyte & S. Asia (India) \\
\hline Commelina benghalensis L. & - & Commelinaceae & Hemicryptophyte & S. Asia \\
\hline Conyza bonariensis (S.Moore) Cufod. & حشيشة الجبل & Asteraceae & Therophyte & Palaeotropical \\
\hline Cuscuta campestris Yunck. & الحامول ـالسوية & Convolvulaceae & Therophyte & S. America \\
\hline Cuscuta chinensis Lam. & - & Convolvulaceae & Phanerophyte & N. America \\
\hline Cynodon transvaalensis Burtt Davy & نجيل برتغالي & Poaceae & Geophyte & S. Asia (China), Australia \\
\hline Datura innoxia Mill. & داتورة & Solanaceae & Therophyte & S. Africa \\
\hline Datura metel L. & داتورة & Solanaceae & Therophyte & S. America \\
\hline Datura stramonium L. & سم الفار & Solanaceae & Therophyte & S. America \\
\hline Dichondra micrantha Urb. & - & Convolvulaceae & Hemicryptophyte & N. America \\
\hline Digitaria violascens Link & - & Poaceae & Therophyte & E. Asia \\
\hline Dinebra retroflexa (Vahl) Panz. & أبو ركبه & Poaceae & Therophyte & Palaeotropical \\
\hline Dysphania ambrosioides (L.) Mosyakin \& Clemants & أبو عفن & Amaranthaceae & Chamaephyte & C. and S. America (Mexico) \\
\hline Eclipta prostrata (L.) L. & سعده & Asteraceae & Therophyte & S. Asia and T. America \\
\hline Eragrostis japonica (Thunb.) Trin. & - & Poaceae & Therophyte & Palaeotropical \\
\hline Eragrostis sarmentosa (Thunb.) Trin. & - & Poaceae & Geophyte & S Asia \& Australia \\
\hline Eragrostis tremula Hochst. ex. Steud. & - & Poaceae & Therophyte & T. Africa, S. Asia \\
\hline Erigeron canadensis L. & - & Asteraceae & Therophyte & T. Africa \& S. Asia (India) \\
\hline Erigeron sumatrensis*Retz. & - & Asteraceae & Therophyte & N. \& S. America \\
\hline Euphorbia heterophylla L. & شربة_لبن الحمارة & Euphorbiaceae & Therophyte & S. America \\
\hline Euphorbia hirta L. & لبين & Euphorbiaceae & Therophyte & C. America \\
\hline Euphorbia hyssopifolia L. & - & Euphorbiaceae & Therophyte & S. of N. America and C. America \\
\hline Euphorbia inaequilatera Sond. var. inaequilatera & الصاب ـالمهياً & Euphorbiaceae & Therophyte & C. America \\
\hline Euphorbia lasiocarpa Klotzsch & - & Euphorbiaceae & Therophyte & S. America (Columbia) \\
\hline Euphorbia mauritanica L. & لبين & Euphorbiaceae & Hemicryptophyte & $\begin{array}{l}\text { C. and S. America (Mexico to Peru, west } \\
\text { Indies) }\end{array}$ \\
\hline Euphorbia prostrata Aiton & لبينة & Euphorbiaceae & Therophyte & S. Africa \\
\hline Euphorbia serpens Kunth & - & Euphorbiaceae & Therophyte & TS America \\
\hline Fallopia convolvulus (L.) Á. Löve & & Polygonaceae & Therophyte & N. America \\
\hline Festuca arundinacea Schreb. & - & Poaceae & Hemicryptophyte & Europe \\
\hline Ficus carica L. & 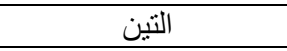 & Moraceae & Phanerophyte & Middle East and W. Asia \\
\hline Galinsoga parviflora Cav. & - & Asteraceae & Therophyte & S. America \\
\hline Gomphrena celosioides* C.F.P.Mart. & - & Amaranthaceae & Therophyte & S. America \\
\hline Heliotropium amplexicaule L. & - & Boraginaceae & Chamaephyte & S. America (Brazil to Argentina, W Indies) \\
\hline Holcus annuus Salzm. ex C.A. Mey. & - & Poaceae & Therophyte & S. America \\
\hline Ipomoea hederacea Jacq. & - & Convolvulaceae & Therophyte & Mediterranean \\
\hline Ipomoea pes- carpae (L.) R. Br. subsp. brasiliensis & لِِلابَة & Convolvulaceae & Hemicryptophyte & C. and S. America \\
\hline
\end{tabular}


Mohamed H. El-Beheiry et al.

\begin{tabular}{|c|c|c|c|c|}
\hline Scientific name & Vernacular name & Family & Life form & Native range \\
\hline Lantana camara L. & ل الانتانا & Verbenaceae & Phanerophyte & T. America \\
\hline Laphangium luteoalbum (L.) Tzvelev & صابون العفريت & Asteraceae & Therophyte & Unknwon \\
\hline Lathyrus sativus L. & سعيدة & Fabaceae & Therophyte & TS America \\
\hline Lepidium didynum L. & رشاد البحر & Brassicaceae & Therophyte & S. America \\
\hline Lepidium virginicum L. & - & Brassicaceae & Therophyte & Europe \\
\hline Ludwigia erecta (L.) Hara & - & Onageraceae & Therophyte & N. America \\
\hline Lycium europaeum L. & عوسج & Solanaceae & Phanerophyte & Europe \\
\hline Matricaria chamomilla* L. & بابونج & Asteraceae & Therophyte & S. Asia (China) \\
\hline Melia azedarach* L. & زنزلخت & Meliaceae & Phanerophyte & Europe \\
\hline Mentha spicata L. subsp. spicata & - & Lamiaceae & Geophyte & SW Asia \\
\hline Merremia dissecta (Jacq.) Hallier f. & - & Convolvulaceae & Hemicryptophyte & Europe \\
\hline Moorochloa eruciformis (Sm.) Veldkamp & نسيلة & Poaceae & Therophyte & Australia \\
\hline Moringa oleifera* Lam. & مورينجا & Moringaceae & Phanerophyte & S. Asia \\
\hline Nicandra physaloids (L.) Scopoli & هدالب & Solanaceae & Therophyte & W. of S. America \\
\hline Nicotiana glauca R. C. Graham & طباق & Solanaceae & Phanerophyte & S. Africa \\
\hline Nicotiana plumbaginifolia Viv. & - & Solanaceae & Phanerophyte & S. America (Argentina) \\
\hline Nicotiana rustica L. & دخان أخضر -دخان بلدي & Solanaceae & Therophyte & S. America \\
\hline Nothoscordum gracile (Aiton) Stearn & - & Amaryllidaceae & Geophyte & S. America \\
\hline Oenothera drummondii Hook. & - & Onageraceae & Chamaephyte & S. America \\
\hline Oxalis corniculata L. & حمد & Oxalidaceae & Geophyte - Helophyte & N. America \\
\hline Oxalis pes-caprae L. & عرق اليمون & Oxalidaceae & Geophyte - Helophyte & Cape of S. Africa \\
\hline Panicum antidotale Retz. & - & Poaceae & Hemicryptophyte & S. Asia \\
\hline Panicum maximum Jacq. & حشيش الجنية & Poaceae & Hemicryptophyte & T. Africa \\
\hline Panicum miliaceum L. & دخن & Poaceae & Hemicryptophyte & T. Africa \\
\hline Paspalum dilatatum Poir. & - & Poaceae & Hemicryptophyte & S. Asia (India) \\
\hline Phalaris arundinacea L. var. picta L. & - & Poaceae & Geophyte & S. America \\
\hline Phalaris canariensis L. & شعير الفأر & Poaceae & Therophyte & Mediterranean \\
\hline Phleum pratense L. & - & Poaceae & Hemicryptophyte & N. America \\
\hline Phyllanthus rotundifolius Willd. & - & Euphorbiaceae & Therophyte & Palaeotropical \\
\hline Physalis angulata $\mathrm{L}$. & - & Solanaceae & Therophyte & N., C. and S. Americas \\
\hline Physalis ixocarpa Brot. ex Hornem. & - & Solanaceae & Therophyte & C. America (Mexico) \\
\hline Plantago exigua Murray & - & Plantaginaceae & Therophyte & C. America (Mexico) \\
\hline Pogonatherum paniceum (Lam.) Hack. & & Poaceae & Geophyte & S. Asia (India) \\
\hline Polygonum aviculare L. & & Polygonaceae & Therophyte & S. Asia \& Australia \\
\hline Populus euphratica Oliv. & 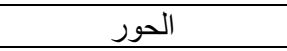 & Salicaceae & Phanerophyte & N. Africa to C. Asia \\
\hline Pycreus polystachyos (Rottb.) P. Beauv. & 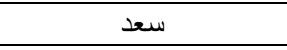 & Cyperaceae & Geophyte-Halophyte & N.\& W. Europe, C. \& N. America \\
\hline Ricinus communis L. & خروع & Euphorbiaceae & Phanerophyte & S. Mediterranean, E. Africa, S. Asia (India) \\
\hline Rubus sanctus Schreb. & ورد بري & Rosaceae & Phanerophyte & Asia and Europe \\
\hline Salix tetrasperma Roxb. & صفصاف كبير & Salicaceae & Phanerophyte & S. and SE Asia \\
\hline
\end{tabular}


Updating the checklist of the alien flora in Egypt

\begin{tabular}{|c|c|c|c|c|}
\hline Scientific name & Vernacular name & Family & Life form & Native range \\
\hline Securigera securidaca (L.) Degen \& Dörfl. & - & Fabacea & Therophyte & SE Asia \\
\hline Sesbania sesban (L.) Merr. & سيسبان & Fabaceae & Phanerophyte & TE Africa (Egypt, Chad, Kenya, Uganda) \\
\hline Setaria megaphylla (Steud.) T. Durand \&Schinz & & Poaceae & Geophyte & T. Africa \\
\hline Setaria pumila (Poir.) Roem. \& Schult. & شعر الفار & Poaceae & Therophyhte & Europe \\
\hline Setaria verticillata (L.) Beauv. & 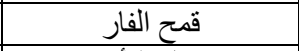 & Poaceae & Therophyte & Europe \\
\hline Setaria viridis (L.) Beauv. & ذيل الفأر & Poaceae & Therophyte & Euro-Asia \\
\hline Solanum elaeagnifolium Cav. & - & Solanaceae & Chamaephyte & Europe \\
\hline Solanum linnaeanum* Happer\&Jaegr & & Solanaceae & Phanerophyte & C. \& S. America \\
\hline Sorghum virgatum (Hack.) Stapf. & ذرة جراوة-حشيش الفرس & Poaceae & Therophyte & S. America \\
\hline Stenotapharum secundatum (Walter) Kuntze & نجيل فرنساوى & Poaceae & Hemicryptophyte & T. Africa \\
\hline Symphyotrichum squamatum (Spreng.) Nesom & - & Asteraceae & Chamaephyte & USA (southeastern), S America \\
\hline Tagetes minuta L. & - & Asteraceae & Therophyte & C. \& S. America \\
\hline Trianthema portulacastrum Lam. & & Aizoaceae & Therophyte & S. America \\
\hline Trifolium alexandrinum L. & برسيم بلدي & Fabaceae & Therophyte & S. America \\
\hline Verbesina encelioides (Cav.) Benth. ex A. Gray & تباع الشمس & Asteraceae & Therophyte & N. and C. America (Mexico) \\
\hline Veronica persica Poir & & Scrophulariaceae & Therophyte & Euro-Asia \\
\hline Withania somnifera (L.) Dunal & مرجان-سم فر اخ & Solanaceae & Chamaephyte & T. Africa \\
\hline Xanthium spinosum L. & شبيط & Asteraceae & Therophyte & S. America \\
\hline Xanthium strumarium L. & شبكة & Asteraceae & Therophyte & N. America \\
\hline Ziziphus spina-christi (L.) Desf. & نبق & Rhamnaceae & Phanerophyte & E..Africa \\
\hline \multicolumn{5}{|l|}{ Invasive } \\
\hline Acacia saligna* (Labill.) H. Wendl. & & Fabaceae & Phanerophyte & W. Australia \\
\hline Azolla filiculoides L. & آزورلا & Azollaceae & Hydrophyte & S. Asia (China, Philippines), Netherlands \\
\hline Bassia indica (Wight) A. J. Scott & كوخيا & Amaranthaceae & Therophyte & W. Mediterranean to E. Asia \\
\hline Dalbergia sissoo* Roxb. & سرسوع & Fabaceae & Phanerophyte & S. Asia (India) \\
\hline Eichhornia crassipes (C. Mart.) Solms & ورد النيل & Pontederiaceae & Hydrophyte & S. America (Brazil) \\
\hline Ipomoea carnea Jacq. & - & Convolvulaceae & Chamaephyte & TS America \\
\hline Prosopis juliflora* (Sw) DC. & غويف، غويفه & Fabaceae & Phanerophyte & C. America (Mexico) \\
\hline
\end{tabular}

